\title{
Comparison of diarsenic oxide and tetraarsenic oxide on anticancer effects: Relation to the apoptosis molecular pathway
}

\author{
HONG-SEOK CHANG ${ }^{1}$, SU-MI BAE ${ }^{2}$, YONG-WAN KIM ${ }^{2}$, SUN-YOUNG KWAK ${ }^{2}$, HYUN-JIN MIN ${ }^{2}$, \\ IL-JU BAE ${ }^{4}$, YOUNG-JOO LEE ${ }^{5}$, JONG-CHUL SHIN ${ }^{3}$, CHONG-KOOK KIM ${ }^{6}$ and WOONG-SHICK AHN ${ }^{3}$ \\ ${ }^{1}$ Department of Therapeutic Radiology, ${ }^{2}$ Catholic Research Institutes of Medical Science, ${ }^{3}$ Department of Obstetrics \\ and Gynecology, College of Medicine, The Catholic University of Korea; ${ }^{4}$ Laboratory of Chonjisan Institute, \\ ${ }^{5}$ Department of Bioscience and Biotechnology, Sejong University; ${ }^{6}$ College of Pharmacy, \\ Seoul National University, Seoul, Korea
}

Received August 11, 2006; Accepted October 26, 2006

\begin{abstract}
As}_{2} \mathrm{O}_{3}$ has been reported to induce apoptosis and inhibit the proliferation of various human cancer cells. We evaluated the ability of a novel arsenic compound, $\mathrm{As}_{4} \mathrm{O}_{6}$, along with $\mathrm{As}_{2} \mathrm{O}_{3}$ in vitro and in vivo. To examine the levels of apoptosis of HPV 16-positive SiHa cervical cancer cell, flow cytometry and Western blotting were employed at various time intervals after two arsenic compound treatments. Ingenuity Pathway Analysis (IPA) was applied to investigate the differential cell death pathway of $\mathrm{As}_{4} \mathrm{O}_{6}$ and $\mathrm{As}_{2} \mathrm{O}_{3}$. The results showed that $\mathrm{As}_{4} \mathrm{O}_{6}$ was more effective in suppressing $\mathrm{SiHa}$ cell growth in vitro and in vivo compared to $\mathrm{As}_{2} \mathrm{O}_{3}$. In addition, the cell cycle was arrested at the sub- $\mathrm{G}_{1}$ phase by $\mathrm{As}_{4} \mathrm{O}_{6}$. Western blot analysis showed that the proliferating cell nuclear antigen (PCNA) and $\mathrm{Bcl}-\mathrm{X}_{\mathrm{L}}$ with sequence homology to Bcl-2 were significantly suppressed by $\mathrm{As}_{4} \mathrm{O}_{6}$. However, the apoptosis-related proteins such as p21 and Bax were overexpressed by $\mathrm{As}_{4} \mathrm{O}_{6}$. IPA suggested that there is a significant difference between $\mathrm{As}_{2} \mathrm{O}_{3}$ - and $\mathrm{As}_{4} \mathrm{O}_{6}$-induced cell death pathways. Taken together, $\mathrm{As}_{4} \mathrm{O}_{6}$ has a specific cell death pathway and possesses more potent anti-tumor effects on human cervical cancer cells in vitro and in vivo.
\end{abstract}

\section{Introduction}

Arsenical compounds $\mathrm{As}_{2} \mathrm{O}_{3}$ and $\mathrm{As}_{4} \mathrm{O}_{6}$ have been demonstrated to possess life-preserving qualities in cancer

Correspondence to: Dr Woong-Shick Ahn, Department of Obstetrics and Gynecology, College of Medicine, The Catholic University of Korea, 505 Banpo-Dong, Seocho-Ku, Seoul 137-040, Korea

E-mail: ahnws@catholic.ac.kr

Key words: cervical intraepithelial neoplasia, diarsenic oxide, tetraarsenic oxide, apoptosis, molecular pathway treatment. Promising results with patients were reported showing that diarsenic oxide $\left(\mathrm{As}_{2} \mathrm{O}_{3}\right)$ treatment could offer an alternative to chemotherapy for acute promyelocytic leukemia (APL) (1-3). Cytopathological studies showed induction of apoptosis in APL cells. Recent reports suggested that arsenical compounds inhibit the proliferation of human umbilical vein endothelial cells (HUVEC) via $G_{1}$ and $G_{2} / M$ phase arrest of the cell cycle. In addition, these inhibitory effects on bFGF- or VEGF-stimulated cell proliferation suggest antiangiogenic potential of these arsenical compounds (4). It has been reported that diarsenic oxide suppresses the growth of tumor cells by cell cycle arrest, induction of cyclin-dependent kinase (CDK) inhibitors and apoptosis in a myeloma cell line, MC/CAR (5). Diarsenic oxide also causes cell death through apoptosis in a human leukemia cell line, NB4 (6), a human papillomavirus (HPV) 16 infected cervical carcinoma cells (7), and a human pancreatic cancer cells (8). On the other hand, tetra-arsenic oxide $\left(\mathrm{As}_{4} \mathrm{O}_{6}\right)$ was reported to have antiangiogenic effects on the new vessels induced by NGF in the rat cornea compared to control group and $\mathrm{As}_{2} \mathrm{O}_{3}$ group (9). It has been suggested that $\mathrm{As}_{4} \mathrm{O}_{6}$ might be a new arsenic compound as it induced apoptosis in U937 leukemic cells at much lower concentration than $\mathrm{As}_{2} \mathrm{O}_{3}$ (10). However, attempts to establish the efficacy of its anticancer activity in vitro and in vivo are technically challenging.

Human papillomaviruses (HPV) have been consistently implicated in causing cervical cancer. Especially high-risk types (HPV 16, 18, 31, 45) have been strongly associated with cervical cancer $(11,12)$. Surgical, radiation, chemotherapies have had only limited success. Also, relapsing cervical cancers are problematic, adding importance to developing anti-cervical cancer drugs.

Here we evaluated the ability of $\mathrm{As}_{4} \mathrm{O}_{6}$ along with $\mathrm{As}_{2} \mathrm{O}_{3}$ to suppress cell growth in HPV 16-positive SiHa human cervical cancer cells. We observe that $\mathrm{As}_{4} \mathrm{O}_{6}$ is more effective in inhibiting the $\mathrm{SiHa}$ cell growth in vitro and in vivo compared to $\mathrm{As}_{2} \mathrm{O}_{3}$. In addition, there is a significant difference in 
functional profiles between $\mathrm{As}_{2} \mathrm{O}_{3}$ - and $\mathrm{As}_{4} \mathrm{O}_{6}$-induced cell cycle and cell death pathways. Thus, these data suggest that a novel arsenic compound, $\mathrm{As}_{4} \mathrm{O}_{6}$ possesses more potent antitumor effects on human cervical cancer cells in vitro and in vivo compared to $\mathrm{As}_{2} \mathrm{O}_{3}$.

\section{Materials and methods}

Cell culture. SiHa HPV 16-immortalized human cervical carcinoma cells were incubated in DMEM supplemented with $5 \%$ fetal bovine serum, $0.37 \%$ sodium bicarbonate, $30 \mathrm{mM}$ HEPES, and $100 \mu \mathrm{g} / \mathrm{ml}$ streptomycin/penicillin (cDMEM) at $37^{\circ} \mathrm{C}$ in a $\mathrm{CO}_{2}$ incubator.

Chemical reagents. $\mathrm{As}_{2} \mathrm{O}_{3}$ was purchased from Sigma (St. Louis, MO). $\mathrm{As}_{4} \mathrm{O}_{6}$ was provided from Chonjisan Co. (Seoul, Korea). These chemicals were diluted in phosphate-buffered saline (PBS) to a final concentration of $10^{-3} \mathrm{M}$ and kept at $4^{\circ} \mathrm{C}$. 3-(4,5-dimethylthiazol-2-yl)-2,5-diphenyltetrazolium bromide (MTT) was purchased from Sigma and dissolved in PBS at a final concentration of $5 \mathrm{mg} / \mathrm{ml}$.

FACS analysis. Cells were washed twice with PBS and then resuspended in $1 \mathrm{X}$ binding buffer $(10 \mathrm{mM} \mathrm{HEPES} / \mathrm{NaOH}$, $\mathrm{pH} 7.4,140 \mathrm{mM} \mathrm{NaCl}, 2.5 \mathrm{mM} \mathrm{CaCl} \mathrm{Cl}_{2}$ ). Per tube $1 \times 10^{5}$ cells were added with $5 \mu 1$ of Annexin V-FITC and $10 \mu 1$ of propidium iodide (BD, San Jose, CA), followed by incubation at $22^{\circ} \mathrm{C}$ for $15 \mathrm{~min}$. Each tube was added with $100 \mu$ of $1 \mathrm{X}$ binding buffer and then the cells were analyzed by a flow cytometer (BD). For DNA contents, ethanol-fixed cells were incubated with RNase A $(10 \mathrm{mg} / \mathrm{ml})$ and propidium iodide $(400 \mu \mathrm{g} / \mathrm{ml})$ and shaken for $1 \mathrm{~h}$ at $37^{\circ} \mathrm{C}$ in the dark. The samples were read using flow cytometer (BD). Cell debris and fixation artifacts were gated out and $G_{0} / G_{1}, S$ and $G_{2} / M$ populations were quantified using the CellQuest program.

Western blot analysis. SiHa cells were treated with 0.5 and $1 \mu \mathrm{M}$ of $\mathrm{As}_{2} \mathrm{O}_{3}$ and $\mathrm{As}_{4} \mathrm{O}_{6}$ for $48 \mathrm{~h}$. The cell lysates $(\sim 30 \mu \mathrm{g}$ of protein) were separated in $12 \%$ polyacrylamide SDS-gels and transferred to a nitrocellulose membrane (Schleicher \& Schuell, Dassel, Germany), which was immersed in blocking buffer (5\% skim milk and $0.1 \%$ Tween-20 in PBS, pH 7.4) for $1 \mathrm{~h}$ at room temperature and incubated with primary antibodies (Santa Cruz Biotechnology, Inc., CA, USA), PCNA (1:200), CDK4 (1:200), p21 (1:200), Bax (1:200), Bcl- $\mathrm{X}_{\mathrm{L}} / \mathrm{Bcl}-\mathrm{X}_{\mathrm{S}}(1: 500)$ and actin (1:5000) in blocking buffer overnight at $4^{\circ} \mathrm{C}$. After the incubation, the membrane was probed with horseradish peroxidase-labeled anti-mouse IgG antibody (1:5000) in PBS (containing of $0.05 \%$ Tween-20 and $5 \%$ skim milk powder) for $30 \mathrm{~min}$ at room temperature. The proteins in the membrane were detected by enhanced chemiluminescence detection system (Amersham, Buckinghamshire, UK) and bands were visualized by autoradiography using $\mathrm{X}$-ray film (Amersham).

Inhibition of tumor growth. Cancer cells $\left(10^{7}\right.$ cells/mouse $)$ in $0.1 \mathrm{ml} \mathrm{PBS}$ were injected into the 6-week-old female BALB/c mice (nu/nu). Fifteen days later, a solution containing $10 \mu \mathrm{g} /$ $\mathrm{gBW}$ of $\mathrm{As}_{4} \mathrm{O}_{6}, \mathrm{As}_{2} \mathrm{O}_{3}$, or PBS was injected into the area where the tumor cells were generated. For four weeks, tumor formation and size were evaluated once in two days. The tumors were measured with calipers for two perpendicular diameters, and tumor size was calculated based on average dimensions. The tumors were resected at the indicated day, and stored at $-70^{\circ} \mathrm{C}$ for analysis. Total proteins were extracted with Trizol as described in the manufacturer's protocol for Western blot analysis.

Pathway identification. As reported previously in cDNA microarray analyses (13), the 108 genes that consistently displayed altered expression patterns in both arsenic compounds were newly analyzed using Ingenuity Pathway Analysis to identify how the transcripts identified by the gene expression signature are related to the cell death signaling pathways. The functional analysis was carried out as follows. Each gene was annotated by integrating the information on the Gene Ontology website (http://GenMAPP.org). First, each gene was associated with its corresponding current curated gene entry in UniGene (http://www.ncbi.nlm.nih.gov). Next, the Ingenuity Pathway Analysis software (IPA, Ingenuity Systems, Mountain View, CA) was utilized to identify networks of interacting genes and other functional groups. Semantically consistent pathway relationships are modeled based on a continual, formal extraction from the public domain literature and cover more than 10,300 human genes (www.ingenuity. com/products/pathways_knowledge.html). These genes were then used as a starting point for generating biologic networks. The resulting networks were represented in graphic format. The files, including results of the Ingenuity are available from our anonymous FTP site: ftp://160.1.9.42/work/arsenicIPA/.

Statistical analysis. Statistical analysis was done using the paired Student's t-test and ANOVA. Values between different groups were compared. A $\mathrm{P}<0.05$ was considered significant.

\section{Results}

$\mathrm{As}_{4} \mathrm{O}_{6}$ induced more early and late apoptotic cell populations in SiHa cells. We counted different apoptotic cell populations induced by these two compounds by double staining the $\mathrm{SiHa}$ cells with annexin $\mathrm{V}$ and propidium iodide (PI). As shown in Fig. 1, the cell death significantly increased after arsenic compound treatment in the SiHa cells. Double positive cell populations (late apoptotic group) were $3.7,3.7$ and $4.8 \%$ at $0.0,0.5$ and $1 \mu \mathrm{M}$ of $\mathrm{As}_{2} \mathrm{O}_{3}$, respectively. Early apoptotic cell populations were $1.4,1.9$ and $4.4 \%$ at $0,0.5$ and $1 \mu \mathrm{M}$ of $\mathrm{As}_{2} \mathrm{O}_{3}$, respectively. However, double positive cell populations were $3.7,8.0$ and $11.5 \%$ at $0,0.5$ and $1 \mu \mathrm{M}$ of $\mathrm{As}_{4} \mathrm{O}_{6}$, respectively. Similarly, early apoptotic cell populations were $1.4,2.5$ and $8.1 \%$ at $0,0.5$ and $1 \mu \mathrm{M}$ of $\mathrm{As}_{4} \mathrm{O}_{6}$, respectively. On the other hand, lower sensitivity to $\mathrm{As}_{2} \mathrm{O}_{3}$ was shown in the $\mathrm{SiHa}$ cells compared to $\mathrm{As}_{4} \mathrm{O}_{6}$. This shows that $\mathrm{As}_{4} \mathrm{O}_{6}$ induced more early and late apoptotic cells compared to $\mathrm{As}_{2} \mathrm{O}_{3}$.

$\mathrm{As}_{4} \mathrm{O}_{6}$ induced apoptosis more significantly than $\mathrm{As}_{2} \mathrm{O}_{3}$. We were next interested in examining the levels of apoptosis achieved by addition of two most sensitive doses, 0.5 and 


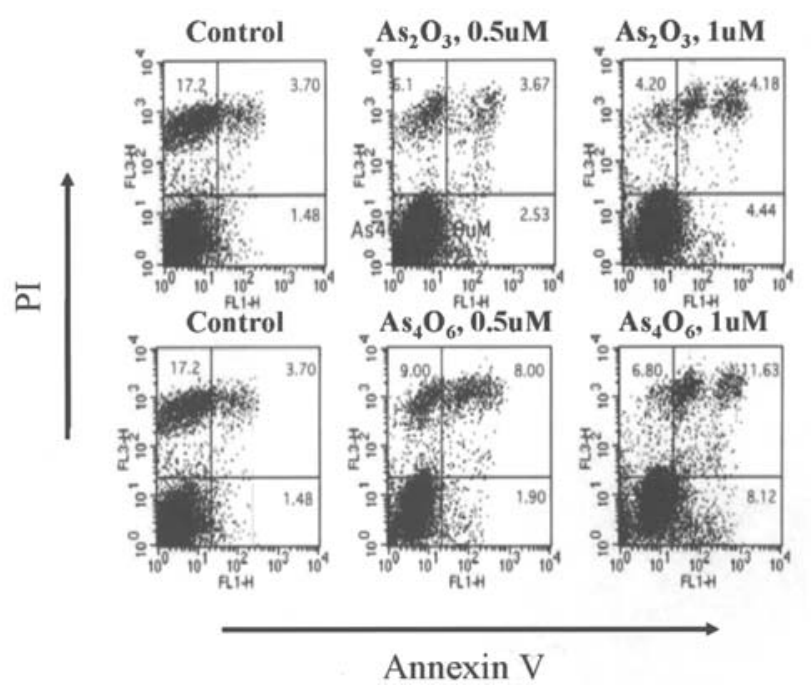

Figure 1. Induction of early and late apoptotic cells in $\mathrm{SiHa}$ cells by $\mathrm{As}_{2} \mathrm{O}_{3}$ and $\mathrm{As}_{4} \mathrm{O}_{6}$.

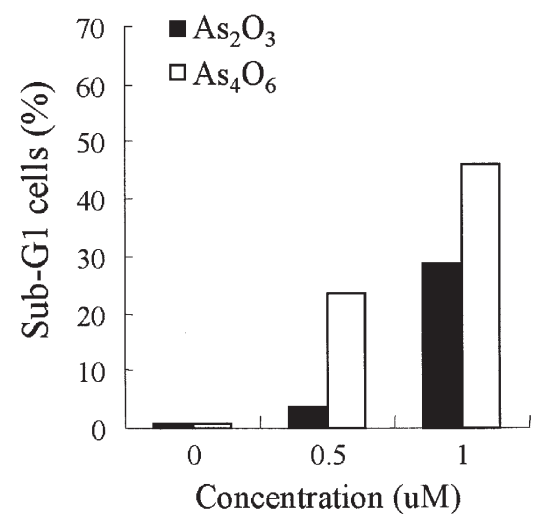

Figure 2. Sub- $\mathrm{G}_{1}$ cell population in $\mathrm{SiHa}$ cells by $\mathrm{As}_{2} \mathrm{O}_{3}$ and $\mathrm{As}_{4} \mathrm{O}_{6}$. Cells were stained with propidium iodide and analyzed using flow cytometer for detection of sub- $\mathrm{G}_{1}$ population.

$1 \mu \mathrm{M}$ of arsenical compounds $\left(\mathrm{As}_{2} \mathrm{O}_{3}\right.$ and $\left.\mathrm{As}_{4} \mathrm{O}_{6}\right)$. As shown in Fig. 2, the apoptosis pattern was confirmed by flow cytometry. In particular, $\mathrm{As}_{4} \mathrm{O}_{6}$ displayed $25 \%$ sub- $\mathrm{G}_{1}$ cell populations at $0.5 \mu \mathrm{M}$. However, little sub- $\mathrm{G}_{1}$ cell populations were observed by $0.5 \mu \mathrm{M}$ of $\mathrm{As}_{2} \mathrm{O}_{3}$. Similarly, $1 \mu \mathrm{M}$ of $\mathrm{As}_{2} \mathrm{O}_{3}$ and $\mathrm{As}_{4} \mathrm{O}_{6}$ showed 30 and $50 \%$ sub- $\mathrm{G}_{1}$ cell populations, respectively. Therefore, the data confirm that $\mathrm{As}_{4} \mathrm{O}_{6}$ significantly induced the levels of apoptosis.

Anti-tumor effects of $\mathrm{As}_{4} \mathrm{O}_{6}$ in mice. To investigate the antitumor effect of arsenic compounds in vivo, we treated $\mathrm{As}_{4} \mathrm{O}_{6}$ with the SiHa cell-xenografted nude mice and then measured each tumor for one month. As shown in Fig. 3, the tumor size increased almost linearly with time in the control group. On the other hand, in the case of $\mathrm{As}_{4} \mathrm{O}_{6}$ treatment, the tumor size was decreased significantly compared to $\mathrm{As}_{2} \mathrm{O}_{3}$ and control. It is, however, notable that the levels of tumor growth inhibition of $\mathrm{As}_{2} \mathrm{O}_{3}$ were not similar with the case of $\mathrm{As}_{4} \mathrm{O}_{6}$. No cyto-

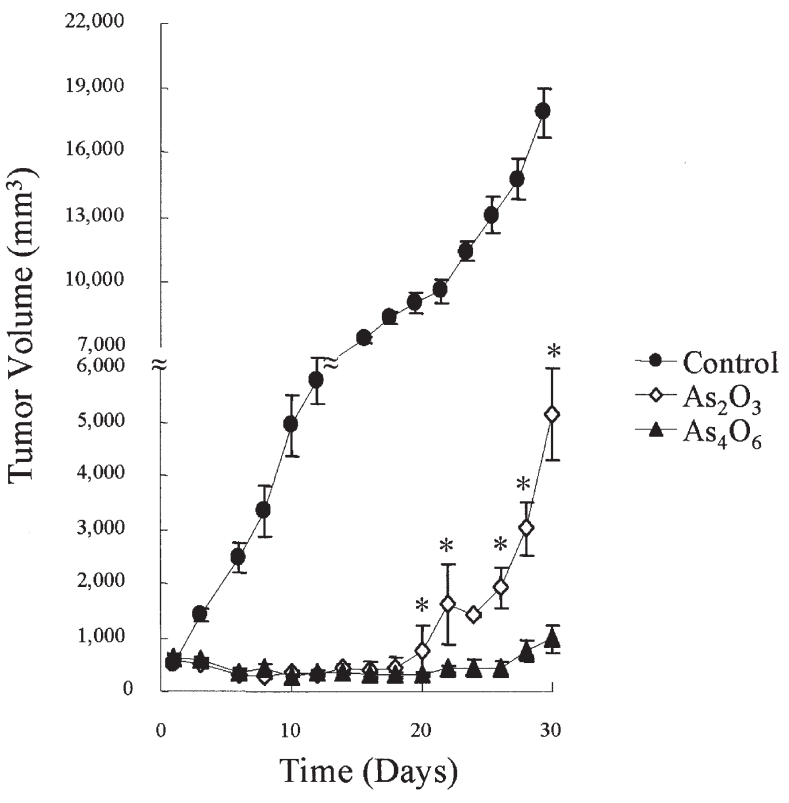

Figure 3. Tumor growth-inhibitory effects of arsenic compounds in $\mathrm{SiHa}$ cell xenografted nude mice. ${ }^{*}$ Statistically significant at $\mathrm{P}<0.05$ using the paired Student's t-test compared to the PBS control $\left({ }^{*} \mathrm{P}<0.05\right)$.

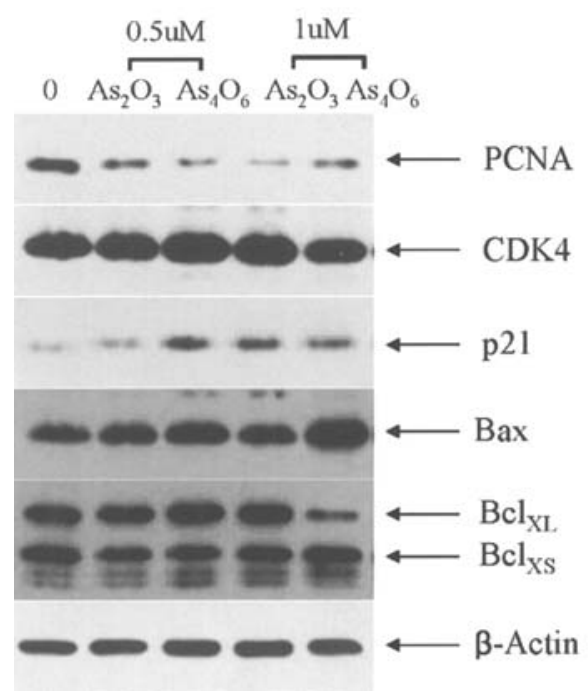

Figure 4. Western blots of cell proliferation marker and apoptosis-related proteins in $\mathrm{SiHa}$ cells by $\mathrm{As}_{2} \mathrm{O}_{3}$ and $\mathrm{As}_{4} \mathrm{O}_{6}$.

toxicity was observed (after 20 days post treatment) with $\mathrm{As}_{2} \mathrm{O}_{3}$ treatment, followed by a rapid increase until the end of the observation period.

Comparison of expression of apoptosis-related proteins by $\mathrm{As}_{2} \mathrm{O}_{3}$ and $\mathrm{As}_{4} \mathrm{O}_{6}$. To compare anti-growth effects induced by $\mathrm{As}_{2} \mathrm{O}_{3}$ and $\mathrm{As}_{4} \mathrm{O}_{6}$ at the levels of cell proliferation- and apoptosis-related proteins, Western blot analysis was performed after treatment with arsenic compounds at 0.5 and $1 \mu \mathrm{M}$. As shown in Fig. 4, the expression of the cell 


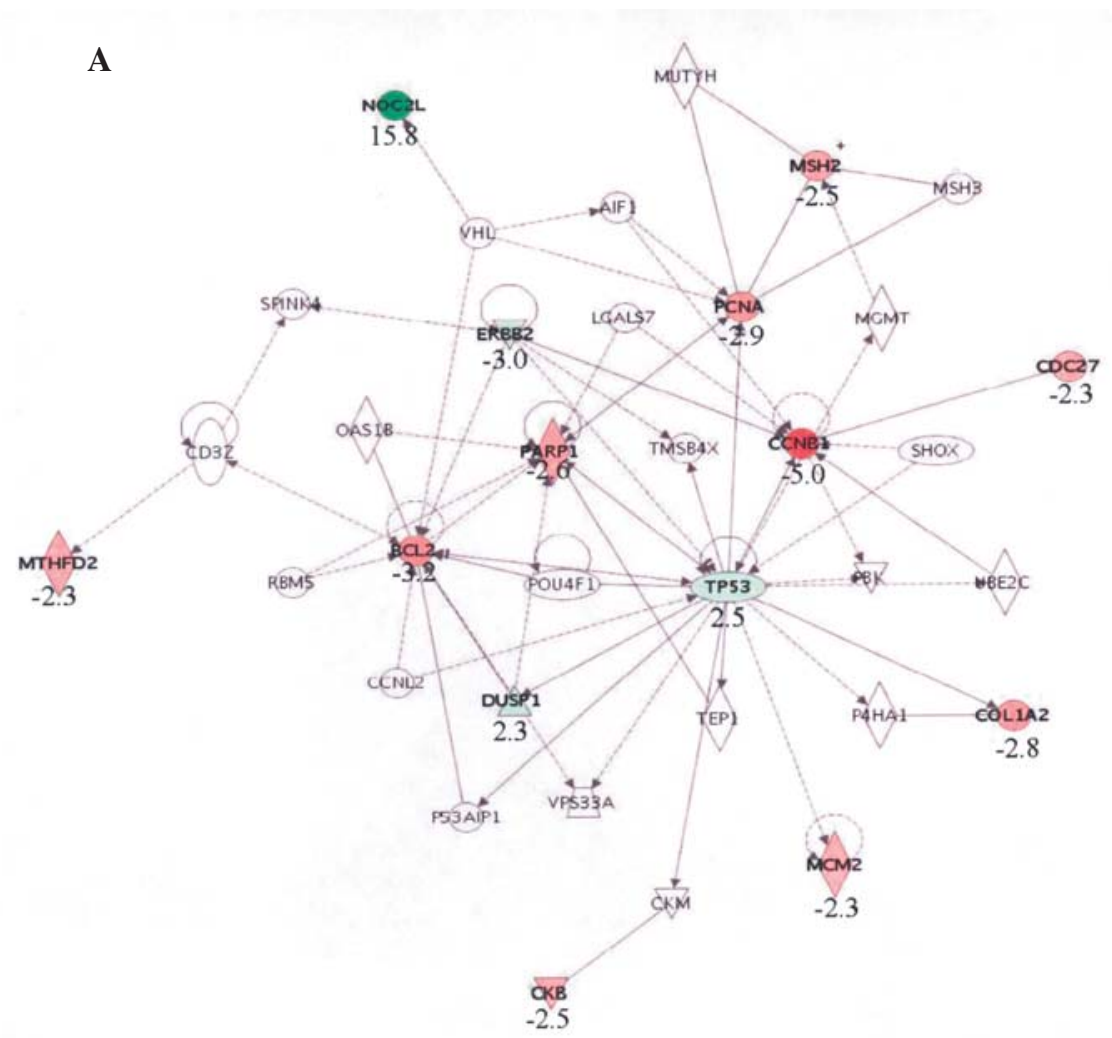

B

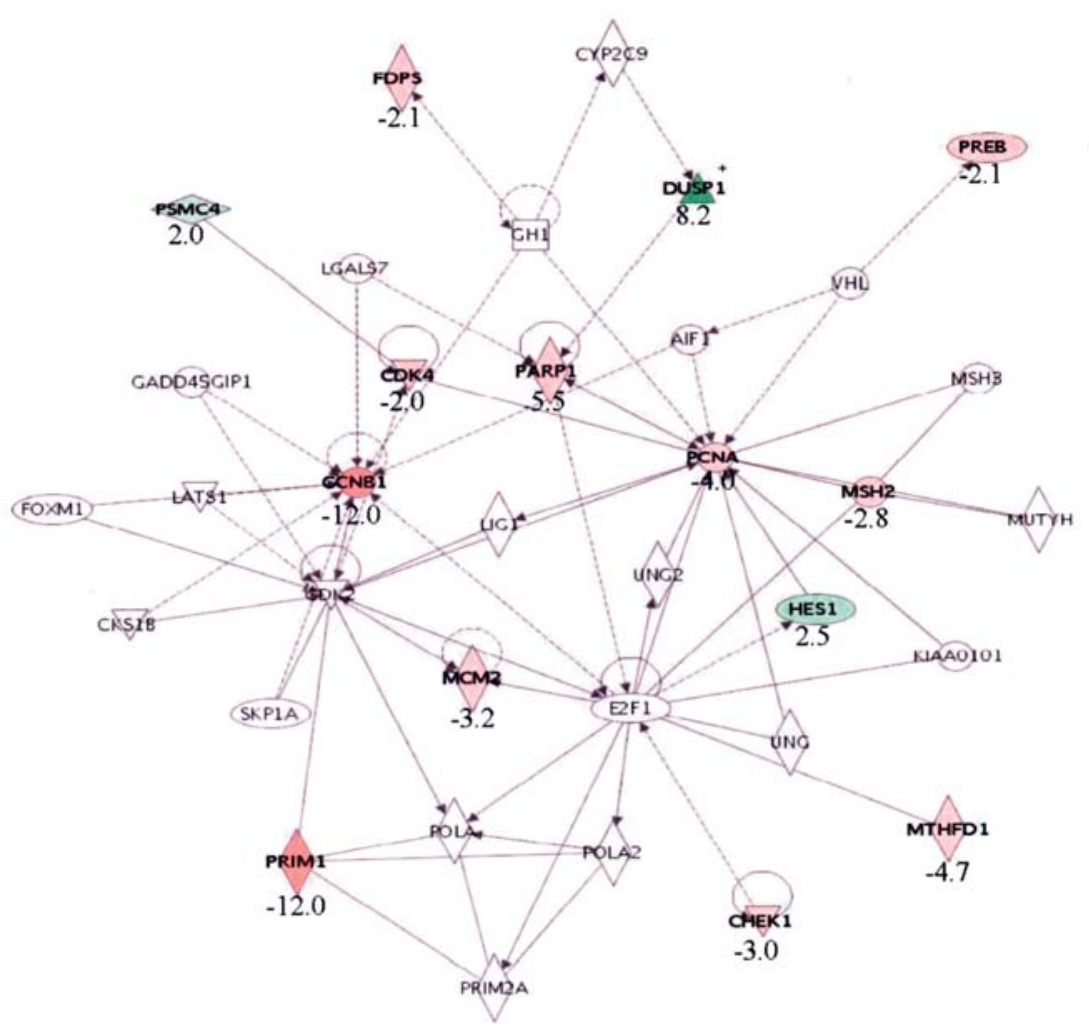

Figure 5. Network mapping of genes with $>2$-fold expression change using Ingenuity Pathway Analysis (IPA). At least 8 genes in the network are involved in the cell death pathway, including PCNA, CCNB1, PARP1, MCM2, CDK4, TP53, ERBB2 and BCL2. Each was differentially regulated by As $\mathrm{O}_{6}$ and $\mathrm{As}_{2} \mathrm{O}_{3}$, respectively. Nodes represent genes, with their shapes representing the functional classes of the gene products, and edges indicate the biologic relationship between the nodes, which include physical and functional interactions. Nodes are color-coded according to their expression levels (red, under-expression; green, over-expression). The fold change of the regulated gene is displayed under the corresponding node. (A) Cell death pathway by $\mathrm{As}_{2} \mathrm{O}_{3}$ treatment and (B) by $\mathrm{As}_{4} \mathrm{O}_{6}$ treatment. 
proliferation marker (PCNA) was down-regulated by these compounds. And the anti-apoptotic protein $\left(\mathrm{Bcl}-\mathrm{X}_{\mathrm{L}}\right)$ was only down-regulated at $1 \mu \mathrm{M}$ of $\mathrm{As}_{4} \mathrm{O}_{6}$ compared to control. In contrast, the expression of apoptosis-related proteins (Bax and p21) was up-regulated compared to the control. Note that $\mathrm{As}_{4} \mathrm{O}_{6}$ inhibited PCNA and $\mathrm{Bcl}-\mathrm{X}_{\mathrm{L}}$ expression significantly compared to $\mathrm{As}_{2} \mathrm{O}_{3}$ at 0.5 and $1 \mu \mathrm{M}$, respectively. Similarly, Bax and p21 expression was significantly increased by $\mathrm{As}_{4} \mathrm{O}_{6}$. However, expression of CDK4 and $\mathrm{Bcl}-\mathrm{X}_{\mathrm{S}}$ was continually expressed by these two arsenic compounds. Taken together, $\mathrm{As}_{4} \mathrm{O}_{6}$ can induce apoptosis through activation of Bax and p21 to a more significant level than $\mathrm{As}_{2} \mathrm{O}_{3}$.

Pathway identification. We first placed the transcripts in the context of the present interactome knowledge using Ingenuity Pathways Analysis tools. Most of these genes were classified into multiple categories and pathways by the software and the Gene Ontology ( $P$ for all $<0.01$ ). In the case of $\mathrm{As}_{4} \mathrm{O}_{6}$ treatment, the main functional networks containing the most statistically robust candidates included the cell death of lymphoblastoid cells $(\mathrm{P}=0.000013)$, accumulation of cervical cancer cells $(P=0.000104), G_{2}$ phase of tumor cells $(\mathrm{P}=0.00035)$, survival of tumor cells $(\mathrm{P}=0.000504)$, and transformation of fibroblasts $(\mathrm{P}=0.000557)$. The genes ( 13 of 19) encoding for apoptosis function were down-regulated (P=0.0043; CHEK1, CSK, MAP4K1, MCM2, MPL, MSH2, NPM1, PARP1, PCNA, PTN, SLK, SPARC, TYMS/ATXN2, CD36, DUSP1, HES1, SERINC3, VAV1). Also, the genes (11 of 13) encoding for cell cycle progression were downregulated $(\mathrm{P}=0.000069$; down-regulation of CDK4, CHEK1, CSK, MCM2, MPL, MSH2, NPM1, PCNA, PPM1G, PPP2R5C, SPARC/up-regulation of DUSP1, VAV1). In contrast, in the case of $\mathrm{As}_{2} \mathrm{O}_{3}$ treatment, the functional networks included arrest in $\mathrm{G}_{2}$ phase of fibroblast cells $(\mathrm{P}=0.000004$, ploidy of tumor cells $(\mathrm{P}=0.0031)$, and cell cycle progression $(\mathrm{P}=0.000041)$. The genes (9 of 12) encoding for apoptosis function were down-regulated ( $\mathrm{P}=0.00167$; MAP4K1, MCM2, MPL, MSH2, NPM1, PARP1, PCNA, SLK, TYMS/TP53, DUSP1, ERBB2). Also, the genes (7 of 10) encoding for cell cycle progression were down-regulated $(\mathrm{P}=0.000041$; GPS 1 , MCM2, MPL, MSH2, NPM1, PCNA, PPM1G/TP53, DUSP1, ERBB2). The results suggested differential expressional patterns of these gene products for the cell death pathway.

We searched the apoptosis-related transcript expression patterns for interaction of additional members of these functional networks. The results of the main network reconstruction by the highest Ingenuity score are shown in Fig. 5. In the case of $\mathrm{As}_{2} \mathrm{O}_{3}$ treatment (Fig. 5A), PCNA, PARP1, BCL2 and CCNB1 central nodes were among the genes constituting the cell death network and were significantly down-regulated at the level of transcription compared to significant up-regulation of P53 and ERBB2. In the case of $\mathrm{As}_{4} \mathrm{O}_{6}$ treatment (Fig. 5B), PCNA, PARP1, CCNB1, MCM2 and CDK4 were significantly down-regulated in the cell death network. In contrast, there is no comparable expression of p53 and ERBB2. The results showed that there is a significant difference in functional networks between $\mathrm{As}_{2} \mathrm{O}_{3}$ and $\mathrm{As}_{4} \mathrm{O}_{6}$-associated cell cycle and death pathways.

\section{Discussion}

$\mathrm{As}_{2} \mathrm{O}_{3}$ has been reported to induce apoptosis and inhibit the proliferation of various human cancer cells derived from solid tumors as well as hematopoietic malignancies $(8,14)$. This supports previous findings that diarsenic oxide induces antitumor effects through induction of tumor cell apoptosis (1-3). On the other hand, $\mathrm{As}_{4} \mathrm{O}_{6}$ has been reported as a novel antiangiogenesis and antimetastasis chemical agent (5). In this study, the results showed that $\mathrm{As}_{4} \mathrm{O}_{6}$ was more effective for suppressing the $\mathrm{SiHa}$ cell proliferation in vitro and in vivo compared to $\mathrm{As}_{2} \mathrm{O}_{3}$. We also injected $\mathrm{As}_{4} \mathrm{O}_{6}$ into mice along with $\mathrm{As}_{2} \mathrm{O}_{3}$ to compare their antitumor effects in mice. As there is no good animal model for inorganic arsenic-related human cancer, we used $10 \mu \mathrm{g} / \mathrm{gBW}$ arsenic doses, higher than the physiological criteria in dietary intakes of inorganic arsenic compounds $(120 \mu \mathrm{g}$ /day females and $214 \mu \mathrm{g} /$ day males) (15). The dose effects of diarsenic oxide on tumor growth inhibition are consistent with many previous reports $(16,17)$. Also, with these doses, it has been reported that no acute toxicity or effect on the body or organ weight of the mice was observed (16).

Anti-proliferating effect of $\mathrm{As}_{2} \mathrm{O}_{3}$ on tumor cells was accomplished by inhibition of cell cycle progression at the $\mathrm{G}_{1}$ phase, $\mathrm{G}_{2} / \mathrm{M}$ phase or both $(14,18,19)$. In the case of $\mathrm{As}_{4} \mathrm{O}_{6}$, it has been reported that induction of cell cycle arrest at $\mathrm{G}_{2} / \mathrm{M}$ phase and inhibition of MMP-2 secretion were possible antiangiogenic mechanisms. This difference might be because of the differential role of the cell-specific apoptotic cell death. We reported the effect of cell-specific p53 adenoviral vector on cervical cancer cells in vitro and in vivo, suggesting that for successful medical treatment of cervical cancer, understanding of the molecular-level of cell-specific growth suppression effects is required (20). In this study, however, the main concern with the study design is that only a single cell line was deployed both in the in vitro and in the animal model. First, in order to validate our experimental approach, these findings should be duplicated in other cervical cancer cell lines and compared with previously reported results. Also, an improved strategy for anti-cancer effect of $\mathrm{As}_{4} \mathrm{O}_{6}$ depending on the cancer cell-dependent pathway should be studied.

In the case of promyeloleukemic cells, $\mathrm{As}_{2} \mathrm{O}_{3}$ downregulates the expression of bcl- 2 and PML/RAR $\alpha / P M L$ proteins which are correlated with apoptosis (2). Also, $\mathrm{As}_{2} \mathrm{O}_{3}$ induces apoptosis in human pancreatic cancer cells through changes in cell cycle, caspase activation and glutathione redox system $(8,21,22)$. In the case of cervical cancer cells, however, it has been reported that expression of human bcl- 2 protein expression does not occur in the $\mathrm{SiHa}$ cells and induction (or repression) of the bcl-2 protein causes no change in the survival of HeLaS3 cells $(23,24)$. Though, $\mathrm{As}_{4} \mathrm{O}_{6}$ is a potent antitumor agent, its precise mechanisms remain unclear. Recently, it has been reported that $\mathrm{As}_{4} \mathrm{O}_{6}$ inhibited the proliferation of human umbilical vein endothelial cells (HUVEC) by degradation of cyclin A, CDC2, and CDC25C. It could also inactivate CDK2 and CDK1 activities, suggesting that apoptosis is a likely mechanism of tetraarsenic oxide suppression of tumor cell growth in vitro and in vivo. 
In this study, we observed that the expression of cell proliferation marker, PCNA, and the anti-apoptotic protein, $\mathrm{Bcl}-\mathrm{X}_{\mathrm{L}}$ was decreased by $\mathrm{As}_{4} \mathrm{O}_{6}$. This is consistent with previously reported results $(25,26)$. PCNA is known to associate with DNA repair processes. Thus, the level of PCNA is known to correlate with DNA repair activity (27). In particular, $\mathrm{As}_{4} \mathrm{O}_{6}$ inhibited PCNA and $\mathrm{Bcl}-\mathrm{X}_{\mathrm{L}}$ expression. Also, the expression of apoptosis-related proteins, Bax and p21 $(25,28)$, was significantly increased by $\mathrm{As}_{4} \mathrm{O}_{6}$ compared to $\mathrm{As}_{2} \mathrm{O}_{3}$. This correlates well with our observation that $\mathrm{As}_{4} \mathrm{O}_{6}$ significantly induced apoptosis in the SiHa cells, in vitro and in vivo.

With the cDNA microarray expression with Ingenuity Pathway Analysis, the results showed that there is a significant difference in functional networks between $\mathrm{As}_{2} \mathrm{O}_{3}$ - and $\mathrm{As}_{4} \mathrm{O}_{6}$ induced cell death pathways $(\mathrm{P}<0.01)$. Especially, as central nodes, proliferation markers MCM2 and CDK4 (cyclindependent kinase 4), which play an important role in onset of DNA replication and cell division were differentially downregulated in the case of $\mathrm{As}_{4} \mathrm{O}_{6}$ treatment compared to $\mathrm{As}_{2} \mathrm{O}_{3}$ treatment. It has been reported that MCM2 expression was present only in normal and some reactive tissues, such as the uterine cervix (29). Also MCM2 became a candidate for an oncogene affected by chromosomal breaks in acute myeloid leukemia (AML) (30). It has been reported that the expression of CDK4 is essential for Ras-induced cancer development, regardless of p53 status or the presence of another frequently mutated tumor suppressor gene, Ink4a/Arf (31). CDK4 suppression has been suggested as a potential therapeutic tool to combat the $\sim 30 \%$ of human tumors in which the Ras oncogene is activated. It has been accepted that genes are mutated in a large number of human cancers. For example, the Ras oncogene is activated in roughly one third of all human tumors, while the p53 tumor suppressor gene is inactivated in half. In light of the frequency with which the Ras oncogene is expressed and the p53 tumor suppressor pathway is disabled in human tumors, the suppression of CDK4 activity was suggested as an alternate point of entry to regulate the cell growth cycle and halt tumorigenesis (32). In the case of $\mathrm{As}_{2} \mathrm{O}_{3}$ treatment, as a central node, the proliferation marker ERBB2 was differentially up-regulated. The ERBB2 protein is a member of a very important group of proteins called receptor tyrosine kinases. During the past decade the role of the ERBB2 oncogene as an important predictor of patient outcome and response to various therapies in breast cancer has been clearly established $(33,34)$. Thus, $\mathrm{As}_{4} \mathrm{O}_{6}$ possesses more potent anti-tumor effects on human cervical cancer cells compared to $\mathrm{As}_{2} \mathrm{O}_{3}$.

In order to understand the relationship of these specific genes to target cancer, it is important to understand the fundamental mechanisms underlying signal transduction by protein-protein interactions. It is proposed that proteins that directly interact with targets will function in important signaling mechanisms. Using Ingenuity Pathway Analysis, several molecules were identified that interact with differentially expressed genes. Understanding the different role of cell death networks is important in designing how therapeutic interventions can be used as novel anti-cancer therapies. The newly identified molecules will be tested to see if parts of the molecule actually has anti-tumor effects.
In conclusion, $\mathrm{As}_{4} \mathrm{O}_{6}$ is more effective for suppressing the $\mathrm{SiHa}$ cell growth in vitro and in vivo compared to $\mathrm{As}_{2} \mathrm{O}_{3}$. In parallel with inhibition of cell proliferation, there is a significant difference in functional networks between $\mathrm{As}_{2} \mathrm{O}_{3}$ and $\mathrm{As}_{4} \mathrm{O}_{6}$-induced cell death pathways. These experiments provided important new information regarding the role of molecular network in mediating apoptosis, possibly through two different pathways. Thus, these findings suggest that $\mathrm{As}_{4} \mathrm{O}_{6}$ possesses more potent anti-tumor effects on human cervical cancer with induction of apoptosis, which might provide a new drug choice for treating HPV-associated cervical cancer.

\section{Acknowledgements}

This work was supported by Korea Research Foundation Grant (KRF-2000-015-FP0047).

\section{References}

1. Shen ZX, Chen GQ, Ni JH, et al: Use of arsenic trioxide $\left(\mathrm{As}_{2} \mathrm{O}_{3}\right)$ in the treatment of acute promyelocytic leukemia (APL): II. Clinical efficacy and pharmacokinetics in relapsed patients. Blood 89: 3354-3360, 1997.

2. Soignet SL, Maslak P, Wang ZG, et al: Complete remission after treatment of acute promyelocytic leukemia with arsenic trioxide. N Engl J Med 339: 1341-1348, 1998.

3. Zhang P, Wang SY, Hu LH, et al: Arsenic trioxide treated 72 cases of acute promyelocytic leukemia. Chin J Hematol 17: $58-70,1996$

4. Woo SH, Park MJ, An S, et al: Diarsenic and tetraarsenic oxide inhibit cell cycle progression and bFGF- and VEGF-induced proliferation of human endothelial cells. J Cell Biochem 95: 120-130, 2005.

5. Park MJ, Park IC, Bae IJ, et al: Tetraarsenic oxide, a novel orally administrable angiogenesis inhibitor. Int $\mathbf{J}$ Oncol 22: 1271-1276, 2003.

6. Gurr JR, Bau DT, Liu F, Lynn S and Jan KY: Dithiothreitol enhances arsenic trioxide-induced apoptosis in NB4 cells. Mol Pharmacol 56: 102-109, 1999.

7. Zheng J, Deng YP, Lin C, Fu M, Xiao PG and Wu M: Arsenic trioxide induces apoptosis of HPV16 DNA-immortalized human cervical epithelial cells and selectively inhibits viral gene expression. Int J Cancer 82: 286-292, 1999.

8. Li X, Ding X and Adrian TE: Arsenic trioxide inhibits proliferation and induces apoptosis in pancreatic cancer cells. Anticancer Res 22: 2205-2213, 2002

9. Yoo MH, Kim JT, Rhee CH, et al: Reverse effects of tetraarsenic oxide on the angiogenesis induced by nerve growth factor in the rat cornea. J Vet Med Sci 66: 1091-1095, 2004.

10. Park IC, Park MJ, Woo SH, et al: Tetraarsenic oxide induces apoptosis in U937 leukemic cells through a reactive oxygen species-dependent pathway. Int J Oncol 23: 943-948, 2003.

11. zur Hausen H: Papillomaviruses in anogenital cancer as a model to understanding the role of viruses in human cancers. Cancer Res 49: 4677-4681, 1989 .

12. Lorincz AT, Temple GF, Kurman RJ, Jenson AB and Lancaster WD: Oncogenic association of specific papillomavirus types with cervical neoplasia. J Natl Cancer Inst 79: 671-677, 1987.

13. Ahn WS, Bae SM, Lee KH, et al: Comparison of effects of $\mathrm{As}_{2} \mathrm{O}_{3}$ and $\mathrm{As}_{4} \mathrm{O}_{6}$ on cell growth inhibition and gene expression profiles by cDNA microarray analysis in SiHa cells. Oncol Rep 12: 573-580, 2004.

14. Park WH, Seol JG, Kim ES, et al: Arsenic trioxide-mediated growth inhibition in MC/CAR myeloma cells via cell cycle arrest in association with induction of cyclin-dependent kinase inhibitor, p21, and apoptosis. Cancer Res 60: 3065-3071, 2000.

15. Watanabe C, Kawata A, Sudo N, et al: Water intake in an Asian population living in arsenic-contaminated area. Toxicol Appl Pharmacol 198: 272-282, 2004.

16. Antimisiaris SG, Klepetsanis P, Zachariou V, Giannopoulou E and Ioannou PV: In vivo distribution of arsenic after i.p. injection of arsonoliposomes in balb-c mice. Int J Pharm 289: 151-158, 2005. 
17. Rodriguez VM, Del Razo LM, Limon-Pacheco JH, et al: Glutathione reductase inhibition and methylated arsenic distribution in Cd1 mice brain and liver. Toxicol Sci 84: 157-166, 2005.

18. Bazarbachi A, El-Sabban ME, Nasr R, et al: Arsenic trioxide and interferon-alpha synergize to induce cell cycle arrest and apoptosis in human T-cell lymphotropic virus type I-transformed cells. Blood 93: 278-283, 1999.

19. Ma DC, Sun YH, Chang KZ, et al: Selective induction of apoptosis of NB4 cells from $\mathrm{G} 2+\mathrm{M}$ phase by sodium arsenite at lower doses. Eur J Haematol 61: 27-35, 1998.

20. Ahn WS, Bae SM, Lee KH, et al: Recombinant adenovirus-p53 gene transfer and cell-specific growth suppression of human cervical cancer cells in vitro and in vivo. Gynecol Oncol 92: 611-621, 2004.

21. Dai J, Weinberg RS, Waxman S and Jing Y: Malignant cells can be sensitized to undergo growth inhibition and apoptosis by arsenic trioxide through modulation of the glutathione redox system. Blood 93: 268-277, 1999.

22. Murgo AJ: Clinical trials of arsenic trioxide in hematologic and solid tumors: overview of the national cancer institute cooperative research and development studies. Oncologist 6: 22-28, 2001

23. Shen MR, Yang TP and Tang MJ: A novel function of BCL-2 overexpression in regulatory volume decrease. Enhancing swelling-activated $\mathrm{Ca}(2+)$ entry and $\mathrm{Cl}(-)$ channel activity. J Biol Chem 277: 15592-15599, 2002.

24. Yin DX and Schimke RT: Inhibition of apoptosis by overexpressing Bcl-2 enhances gene amplification by a mechanism independent of aphidicolin pretreatment. Proc Natl Acad Sci USA 93: 3394-3398, 1996.

25. Mitchell KO, Ricci MS, Miyashita T, et al: Bax is a transcriptional target and mediator of c-myc-induced apoptosis. Cancer Res 60 : $6318-6325,2000$
26. Takehara T and Takahashi H: Suppression of Bcl- $\mathrm{X}_{\mathrm{L}}$ deamidation in human hepatocellular carcinomas. Cancer Res 63: 3054-3057, 2003.

27. Katsumi S, Kobayashi N, Imoto K, et al: In situ visualization of ultraviolet-light-induced DNA damage repair in locally irradiated human fibroblasts. J Invest Dermatol 117: 1156-1161, 2001.

28. John LS, Sauter ER, Herlyn M, Litwin S and Adler-Storthz K: Endogenous p53 gene status predicts the response of human squamous cell carcinoma to wild-type p53. Cancer Gene Ther 7: 749-756, 2000.

29. Freeman A, Morris LS, Mills AD, et al: Minichromosome maintenance proteins as biological markers of dysplasia and malignancy. Clin Cancer Res 5: 2121-2132, 1999.

30. Mincheva A, Todorov I, Werner D, Fink TM and Lichter P: The human gene for nuclear protein BM28 (CDCL1), a new member of the early S-phase family of proteins, maps to chromosome band 3q21. Cytogenet Cell Genet 65: 276-287, 1994.

31. Zou X, Ray D, Aziyu A, et al: Cdk4 disruption renders primary mouse cells resistant to oncogenic transformation, leading to Arf/p53-independent senescence. Genes Dev 16: 2923-2934, 2002.

32. Yu Q, Sicinska E, Geng Y, et al: Requirement for CDK4 kinase function in breast cancer. Cancer Cell 9: 23-32, 2006.

33. Yu D and Hung MC: Overexpression of ErbB2 in cancer and ErbB2-targeting strategies. Oncogene 19: 6115-6121, 2000.

34. Borg A, Baldetorp B, Ferno M, Killander D, Olsson H and Sigurdsson H: ERBB2 amplification in breast cancer with a high rate of proliferation. Oncogene 6: 137-143, 1991. 